\title{
FORBIDDEN SOUNDS: EXPLORING The SiLenCes Of MUSIC HISTORY
}

\author{
Elijah Wald
}

Before I became a music historian I was a musician, and for five years in the 1990s I played guitar for Howard Armstrong - professionally known as Louie Bluie - an African American fiddle and mandolin player from eastern Tennessee. Howard was born in 1909 and made his first records in 1931 with a guitarist named Ted Bogan. Since Howard and Ted were black musicians from the rural South and they recorded during the blues era, history remembers them as blues musicians. But I worked with Howard in a lot of different situations, and can make a confident guess about what he would have played at a conference of German-language musicologists. He was always proud of his ability to make his audiences feel welcome, so would have performed his version of $» D u$, du liegst mir im Herzen« (Armstrong 1998).

Howard sang songs in German, French, Spanish, Italian and Polish, and his dance repertoire included polkas and waltzes along with blues, ragtime, and square-dance tunes. There were lots of immigrants working in the coal mines in his part of Tennessee, and if you wanted to make a living as a musician it was good business to know appropriate music for any and all your potential customers. But he never recorded anything but blues and ragtime in the 1930s, and even when he and his playing partners were $» r e-$ discovered « in the 1970s they tended to stick to blues and swing music (though they did record a version of "Chinatown, My Chinatown « that included a verse in what Howard swore was Mandarin Chinese). His German waltz only happened to be recorded in 1985, when he was 76 years old, because someone made a documentary film about his life (Louie Bluie, 1986) and he talked about his youth among European immigrants and played a few of the songs he used to play for them.

I tell this story both because it suggests how limited the common view of African-American rural music may be, and because all of us, whoever we are and whether or not we are professional musicians, know songs that we 
would never care to record. Even if we cared to record those songs, most of us would not find anyone who was interested in hearing them. I have done fieldwork, and tried to be very broadminded about what material I preserved, but it is never possible to record everything, so one makes choices.

The Haitian historian Michel-Rolphe Trouillot (1995: 152) has written that »narratives are made of silences, not all of which are deliberate or even perceptible [...] within the time of their production. « His point is that history consists of what is left out of stories as well as what is included, and he is not protesting that fact. There will always be more left out of history than is included, simply because there is no way to collect information about more than a tiny fraction of human activity or interchanges, much less to organize that information and make any sense of it. Sometimes information is suppressed or left out on purpose, but far more often it is left out because people simply fail to notice it or to consider it important.

Perhaps the single greatest problem for historians is that people virtually never notice the things that are most common and fundamental in their lives and societies. Jorge Luis Borges (2000) once pointed out that if we needed to establish that the Koran was written by an Arab, the proof is that it makes no mention of camels. Similarly, there is an old saying that »We don't know who discovered water, but we can be sure it was not a fish. «

Academic researchers are no better about this than anyone else - they have different agendas than other people, but are just as inclined to miss what is right under their noses, or to consider much of what they observe too trivial to deserve attention. And the silences are not just a matter of what gets recorded or preserved. Trouillot writes,

»silences enter the process of historical production at four crucial moments: the moment of fact creation (the making of sources); the moment of fact assembly (the making of archives); the moment of fact retrieval (the making of narratives); and the moment of retrospective significance (the making of history)« (Trouillot 1995: 26).

Starting at the beginning: One of my crusades as a pop music historian is to emphasize that recordings are a very limited and misleading resource. Pop records were never made with the intention of providing a balanced picture of the music of a place and time; they were made to suit the market of record listeners. That severely limited what was recorded, and not just because some styles of music were not commercial. Even within the most commercial styles, when people went to a dance they wanted the band to play their favorite songs - for my generation, that was usually Motown hits - but very few people would have ever bought a record of those songs by 
that band, because if they wanted recordings of those songs they would buy the Motown records.

That is why the only recordings we have of Robert J ohnson or Muddy Waters are records of blues, although both of them played lots of current pop hits for dances in rural Mississippi. Johnson's peers recalled that in the 1930s he could play anything he heard on the radio and could yodel like J immie Rodgers (Obrecht 1993: 13). In the early 1940s, Waters's list of songs he was playing at dances included things like »Chattanooga Choo-Choo, « and a half-dozen Hollywood cowboy songs (Lomax 1993: 413-14). But when people wanted records of jazz or cowboy music, they bought Count Basie, Glenn Miller, or Gene Autry records. As a result, records are a very misleading source for what Robert J ohnson or Muddy Waters played in person, or for what was played by anyone at dances in rural Mississippi. This is equally true within single genres: when they sang blues, artists like Waters and J ohnson performed the current blues hits made famous by record stars like Leroy Carr far more frequently than they played the less widely-known songs they recorded themselves - but since those hits had already been done by Carr, there was no reason to record them again. ${ }^{1}$

One might expect records to be a better source for urban music, or for what was performed by major stars, but many of the same problems hold. I often use the example of Louis Armstrong in the second half of the 1920s, which many jazz historians consider the peak of his artistic career. They base that assessment on the records he made during this period with his »Hot Five« and »Hot Seven, « two of the most influential recording groups in jazz. But those groups were only recording groups. Their total career as ensembles consisted of 27 days of recording, spread out over several years.

During those same years, Armstrong was working seven days a week, for six or eight hours every day, in the Vendome theater orchestra and Carol Dickerson's dance orchestra. Each of those groups recorded only one record - about five minutes of music each. So Armstrong had two completely separate careers in that period, one as a recording artist and the other as a live performer. And they were with very different groups, playing very different kinds of music. For example, his specialty with the theater orchestra was

1 As long as live performers were standard at dances, those performers were expected to play the current hits and audience favorites, and that was true whether the audience wanted blues, country, swing, polkas, or Mexican music. In the early 1960s, the Chicago bluesman Buddy Guy recalled, »every joint we played in had a juke box and if you couldn't play those Top 10 numbers on the juke box, you wasn't gonna play in this club! (Notes to The American Folk Blues Festival 1962-1969, Volume Three, Hip-O Records B0002937-09). 
the intermezzo from the Italian opera Cavalleria Rusticana. He never recorded that, or anything like that, so we can never know how it sounded to hear Louis Armstrong play it - although it is what he was playing for the public every day when he was at the peak of his artistic powers (J ones/ Chilton 1988; Rust 1969).

I'm sorry I can't hear how Armstrong played classical arias, but I understand the reasons. There were hundreds of trumpeters playing Cavalleria Rusticana in that period, including internationally famous concert virtuosos - so why record a version by a young black dance musician in Chicago?

One might argue that although records don't provide a full picture of what was played in a given period, at least they give us a good picture of what was recorded and sold on phonograph records. But there we come to the making of archives: During the same period when Armstrong was making a name for himself in Chicago, Guy Lombardo and the Royal Canadians became the most popular dance band in that city and then in the whole United States. Lombardo's orchestra remained one of the most popular and influential bands in the United States for the next fifteen or twenty years, ${ }^{2}$ and there was never a year in that period when they did not sell more records than Louis Armstrong, or get more radio play, or get heard by more people, or get imitated by more musicians. And Lombardo made hundreds of recordings. But try to find a serious study of Lombardo's music, or an archive where a scholar could hear all of those records. It does not exist, because jazz collectors wrote the histories and assembled the archives and they did not like Lombardo's music. In fact, most of them hated Lombardo's music.

Once again, I understand that. I tend to listen to music I enjoy or admire, and Lombardo is not to my taste, even though I know how popular he was. But we have to recognize the problem this creates: There has often been a huge divide between the music most people play, or hear, or dance to, and the music that is recorded. And when it comes to recordings, there is also a huge divide between the recordings most people buy, or hear, or

2 The Royal Canadians consistently won magazine polls as the favorite "sweet « dance band in the United States from the late 1920s until such polls stopped being compiled. In 1930, Lombardo even set an attendance record at Harlem's Savoy Ballroom, the top African American dance venue in New York (Allen 1974). He continued to be successful long after the end of the big band era through the 1970s his orchestra still broadcast nationally as part of the annual New Year's Eve celebration from New York's Times Square, watched across the country. His record sales tend to be estimated at over 100 million units (Whitburn 1986), and Billboard magazine was still reporting new million-selling hits by him in the 1950s. 
dance to, and which recordings are archived and studied by people like me or anyone likely to be reading this paper.

There are many reasons for this, but one is that there is typically a huge divide between people who care about preserving and analyzing music and people who just like to dance. I often describe that divide in a way that is kind of a joke, but also uncomfortably true: The typical consumer of Western popular music is a teenage girl who likes to dance, while the typical critic or scholar is a man who had no dates in high school. So not only is he different from the typical pop music consumers, he tends to hate the typical consumers and their music.

There are now fortunately many more women writing about popular music than there used to be, but they are still a minority, and they are still not typical consumers - anyone who becomes a musicologist is by definition not typical of the general population.

This brings me to the most popular German band of the 1970s - and not only in Germany: When I was living in Spain in the late 1970s, the most popular band on the radio, in discothèques, or that I heard walking down the street, was a German band. I am sure pretty much anyone reading this will remember it, because it was probably the most popular band in Europe. It was called Boney $M$, and sold between fifty and a hundred million records, ${ }^{3}$ not to mention the radio, discotheque, television, and background music replays that made their music ubiquitous around the world.

Admittedly, none of the performers pictured on Boney M's album covers or shown in their videos was German - Bobby Farrell, the frontman, was from Aruba and the women were from J amaica, Montserrat, and elsewhere in the West Indies - but the records were made in Germany, the male voice on the recording (too which Farrell lip-synched) was a German - Franz Reuther, known as Frank Farian - who was also the producer, and as far as I know the musicians were all Germans. But no one in Germany or elsewhere has ever published any serious study that deals with Boney $M$. When I searched in one of the largest databases of academic journals (J STOR), I could find only about a dozen papers that even mentioned the group's name. Only two mentioned which country it was from: one (Starr 1983) described it as »The British rock group Boney $M$ « and the other (Rijven 1989) was more accurate but had a different problem, calling it »the German

3 Record sales numbers for top groups are always suspect and frequently variable: Billboard magazine printed an estimate of 100 million worldwide sales for Boney M's records on 26th December 1981, an estimate of 40 million albums and 65 million singles on 27th J une 1992, and an estimate of 60 million total on 11th December 1999. 
disco disaster. "None of the articles gave any more information than that. None even vaguely suggested how popular Boney $\mathrm{M}$ was, or the possibility that it might have been a significant influence on other bands and artists, or that there is any reason why anyone, anywhere might ever want to study it.

So, what is Boney M's place in history? Does it have one? Does that matter? At this point I must emphasize that this is not a paper about my favorite artists or bands. I was never a fan of Guy Lombardo, and I never listened to Boney $\mathrm{M}$ except by accident. But I am not emphasizing that fact in order to demonstrate my good taste - I am not saying, »Don't worry, it's OK, I don't think Boney M made great music. « I am emphasizing that because I think one of the great problems with popular music scholarship and also with classical music scholarship and scholarship on art in general is that researchers feel free to base their work on what they and their colleagues like. Imagine for a minute how political history would be written if it were based on what scholars like: I often say that if political historians wrote the way music historians write, they would leave Hitler and Stalin out of histories of the Twentieth century. We don't like their work, so why write about them?

There is an obvious response to that analogy: It is important to remember Hitler and Stalin because if we forget about them we run the risk of repeating those horrors. But if we forget bad art - even very popular bad art - what harm does that do?

The answer is that if our only interest in art is to enjoy it, and the only people we care about are people like us, we can ignore the art we don't like. But if we want to understand music and its place in society - to understand the people who make it, the world in which it is made, the reasons why some people enjoy certain music and others don't, and how music evolves and changes - we cannot ignore music just because it fails to suit our personal tastes or is generally disliked by our friends and colleagues.

I am not saying we should only study the biggest stars and the most popular hits. There are plenty of good reasons to study marginal styles and artists, not only because their work is often fascinating but because it can provide unique insights about the broader culture and music of their times and places. But our discipline is popular music studies, so I think we are obligated to at least attempt to understand which music is popular, and why it is popular. I often read articles in which a scholar argues that some style of music represents the feelings of a particular culture, then quotes a song lyric that perfectly exemplifies this point - but it is a song that was not popular within that culture. This makes for a cohesive academic paper, but misrepresents the culture's musical taste. 
For example, the sociolinguist Roxy Harris did extensive work among British Asian youth and noted that virtually every article on the music of this group focused on bhangra as representing their transnational identity but he found that if he simply asked young British Asians about their favorite music, they tended to list the same artists their non-Asian peers liked and very rarely mentioned bhangra (Harris 2006). As a unique fusion style, bhangra is a fascinating example for musicologists who want to explore transnational tastes, but that is a statement about musicologists, not about transnational tastes. I have often found such silences not only in other scholars' work but in my own. If I am interested in studying a style of music I tend to talk to people who are involved in that style, and to ask them questions related to that style - and it is easy to forget that the result is a study of my interest and how I pursued it, and may not reflect the interests even of my informants, much less the interests of their friends, neighbors, or communities.

I find this sort of thing particularly common in writing about rap: academic articles routinely focus on rap recordings that express or exemplify social views or relationships, rather than on which rap recordings are popular. Since rap is routinely demonized by many sectors of society, it is natural for scholars who love rap to celebrate its role as a »voice of the voiceless « and a forum for social criticism. Nor is there anything wrong with that - but it is important to distinguish such values from claims of popularity. One often finds writers noting the popularity of rap in a particular region, then quoting the lyrics of a socially conscious rap song from that region, without noting that the particular song quoted was not a hit. Such a presentation implies that the popularity of rap goes hand in hand with its social consciousness - which is true in some situations, but false in others. Party raps are far more popular than »conscious « raps in many neighborhoods, and while that does not mean a scholar should exclusively or primarily study party raps, it does mean that if we want to understand the role of rap or hip-hop in those neighborhood we need to be aware of such discrepancies.

Many musicologists feel that it is not a requirement of their discipline to interview musicians or consumers - that such interviews are the province of ethnomusicologists - but no good discipline is based on willful ignorance. I once heard a professor in Boston claim that a particular song was the anthem of young Cape Verdeans in New England, known to everyone in the community - and then simply dismiss the response of some local Cape Verdean students who said they had never heard it. I have no doubt he had done solid research, but he was missing a good opportunity to do more. 
Which is to say, we need to listen to recordings, but we also need to listen to people, and we need to be especially attentive when they disagree with us.

Going back to Louis Armstrong and Guy Lombardo: a few years ago, I became interested in the fact that in interviews conducted over several decades, Armstrong consistently named Lombardo as his favorite band. ${ }^{4}$ J azz fans, critics, and historians all tend to hate Lombardo, so they simply leave him out of jazz history - and if you ask why, they will say because his music was not jazz. But they tend to agree that Louis Armstrong was the most important jazz artist of the twentieth century. And the more I thought about that, the more I was struck by the paradox of scholars claiming to be doing detailed explorations of Armstrong and his music while completely ignoring the group he consistently called his favorite band.

As it turned out, exploring that paradox took me down some interesting pathways: first a study of Armstrong's relationship to »sweet « jazz and classical music (Wald 2007) and then a broader study of jazz history that became the core of my book How the Beatles Destroyed Rock ' $n$ ' Roll (Wald 2009). That book was an attempt to write a social history of popular music in the United States, looking at what was most popular in various periods and how it evolved, and trying to understand why it was popular, and with whom. It was also a sort of academic exercise: I realized that if I was serious about studying popular styles, I needed to listen to a lot of music I had always disliked or avoided, and to take it seriously, without making judgments about whether it was good or bad.

The title of my book might seem to run counter to that exercise - a lot of people understood it as an attack on the Beatles, and some were very upset by it. But when people challenge me about it, my response is to suggest that they find someone they know and trust - a relative or a friend - who was playing in a rock ' $n$ ' roll band in the early 1960s, and ask what my title means. Because anyone who was playing in a band during that period can explain it. Of course it is a shamelessly sensational title, designed to sell books, but it also highlights a straightforward historical fact: when the Beatles became the dominant force in rock, that destroyed the world of rock ' $n$ ' roll dance bands - because their innovations fundamentally changed popular music and the previous style was no longer relevant.

If you want a sense of what the older rock ' $n$ ' roll dance bands sounded like, a good example would be the version of »Shout « preserved from a

4 Armstrong's affection for Lombardo's band is mentioned in virtually every Armstrong biography (e.g. Collier 1983; Jones/Chilton 1988) and many magazine articles, but rarely explored in any depth. 
television broadcast by the Beatles in April 1964 (Beatles 1995). ${ }^{5}$ Like most of the bands who played that song, the Beatles just performed it at dances and never bothered to put it on a record. Even the original record of the song, by the Isley Brothers, was not a big hit. So, given my stress on popularity, why do I pick it as an example? A few years ago I interviewed the rockabilly singer Dale Hawkins and he mentioned that by the early 1960s he was touring with a horn section, and since that doesn't fit the rockabilly style I asked him what music he was playing. His answer was: »Back then if you didn't play >Shout< you might just as well stay home« (Wald 2009: 221).

I had never thought about »Shout « as being particularly important, and as far as I know, no other writer ever singled it out as a major song of that time. But in the ten years since that interview, every time I meet anyone who was in a rock ' $n$ ' roll band in the early 1960s I ask them, and they all agree: They all had to play »Shout, « because dancers loved it. None of them recorded it, because there was no reason to - its function was to get a crowd of dancers excited, in that moment. And when rock ' $n$ ' roll dance bands disappeared, that song pretty much disappeared along with them. And since the history of rock was written primarily by record collectors, we all missed its importance.

In my recent research I keep coming back to dancing as a key to understanding pop music tastes and trends, in part because as a musician and musicologist I am tempted to give music more weight than it deserves. People like me tend to miss the fact that for most people music is almost always part of a larger experience, and one of its primary functions is as the audio soundtrack for a night of dancing. We also tend to ignore or deny the fact that dancers are just as severe in their criticisms and judgments as scholars are - though their standards are often very different - and that dancing is a particularly intense way of understanding and absorbing music. So it can be very salutary to pay attention to dancing and to be aware of the extent to which musical tastes and evolutions are shaped by physical relationships between people rather than by the sounds that individuals choose to play or listen to. Academic scholars find it particularly easy to miss or avoid this fact, because Western academic culture values the mind over the body.

While noting that historical silences are often unconscious, Trouillot (1995: 118) emphasizes that they always reflect »narratives of power « who was noticed and who was not; what was preserved and what was not; who is now doing the research and who is not, and where, and why they are doing it, and whether or not that research reaches an audience. The

5 Although this simulates a live performance, it is in fact lip-synched to a recording made specifically for this broadcast. 
mind/ body division clearly reflects such a discourse of power: It involves gender, since dancing in our society tends to be something women like to do more than men. And race, since most of our dance music in the last hundred years can be traced back to African roots and is connected to stereotypes about primitive physicality. And class, of course, because physical work tends to be done by people who do not have much money or power. I suggested before that some of the silences in our history are due to the fact that much of the music we hear is so common that we regard it as trivial. But at times it is also because we regard some people and their tastes as common and trivial.

Those power relationships are hardly news in modern academia, but they are always worth emphasizing and perhaps need special emphasis in popular music studies. I continue to see a lot of academic attention being paid to music favored by men who don't dance - for example, punk, and rap, and heavy metal - while a lot of other, often more popular music is ignored. The focus on these forms is frequently defended as an attempt to stand up for some sector of disenfranchised youth for whom the music functions as an alternative discourse - poor African American kids, or poor urban white kids, or poor immigrant kids. That is all fine and reasonable, but when the sort of scholars who used to study jazz and classical music and who argued for the special value of those musics, as compared to the stupid pop music the teenage girls liked - now choose to focus on other styles favored by non-dancing males, I can't help noticing that there is a degree of continuity.

This gender gap is particularly interesting to me because it is so pervasive. Katy Perry, for example, has a gigantic international audience and when I watch her videos and read her interviews I see numerous potential angles for academic study. But a lot of very smart, thoughtful people in academia - women as well as men - react to that statement by just rolling their eyes and saying, »Oh no, not Katy Perry... (The exceptions to this prejudice are equally telling: Madonna, and more recently Lady Gaga, have attracted plenty of academic attention, but that attention almost always focuses on the ways in which they subvert common teen-girl pop star images and stereotypes - a fancy way of saying they are weird rather than cute.)

There is obviously a great deal more that could be said on this subject, but I would like to end by suggesting some unexplored lines of research that might be particularly fruitful to a German-speaking audience. 


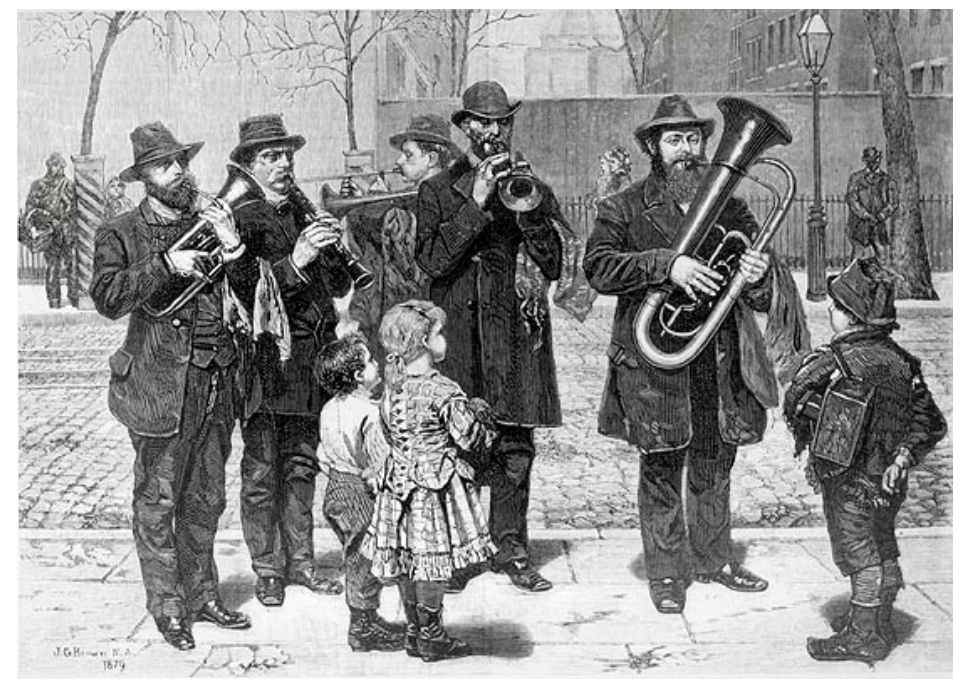

Image 1: J ohn George Brown, »The German Band, « published in Harper's Weekly, 26 April 1879.

If we look at the band in image 1 , and consider only the instrumentation, it looks very much like a New Orleans jazz band. That picture is from 1879, and it was titled »The German Band. «There were hundreds of German bands like that all over the United States. And the connection with New Orleans jazz might be worth exploring. George Baquet, one of the first New Orleans jazz artists to tour outside that city, suggested that there was at least some influence, recalling that his band went on »a hustling trip all over Dixie...just like the German bands used to do (Gushee 2005).

The players in those German bands were not necessarily German, nor was their music - I find descriptions of German bands playing »Old Black Joe« and »Swanee River (Biggers 1911). But my impression is that they were originally associated with beer gardens and did play German and Austrian tunes. This is especially interesting to me because I work a lot on Mexican music, which means I am listening to a lot of modern music that is directly descended from the style of these German bands. Even some of the old repertoire remains current: plug the words »banda « and »Sobre las olas « into YouTube, and you will find an array of current pop brass bands playing one of the classic waltzes of the late nineteenth century. Indeed, until I began studying Mexican music, I thought »Über den Wellen « was a Viennese waltz, though it was written by the Mexican composer J uventino Rosas. And this mistake turned out to be a clue to a deep relationship: German music importers and publishers dominated the Mexican market in the late $19^{\text {th }}$ century (Heath 2007), and Rosas's tune was originally issued in Mexico City by the company of Wagner y Levien. Today, the German brass band style known as banda is carried on by groups that sell millions of records in both Mexico and the United States, and there is a terrific book on this by a Swiss 
ethnomusicologist named Helena Simonette, who did a lot of her research by dancing in Los Angeles nightclubs. Simonette (2001) notes that banda has its roots in the bands formed by German breweries on Mexico's west coast, and that some older musicians still think of it as a German style.

The music of the Texas border region was also heavily influenced by German and Bohemian bands, though there it tends to be played with accordions rather than brass instruments. Recently, the bandas and accordions have been challenged by a new style called música duranguense, which comes from Chicago, but much of the music still sounds very much like Central European polka: for example, the perky hit record of »El sube y baja « by Grupo Montez de Durango (2002). Although duranguense music has been one of the most popular styles in the United States and Mexico for about ten years now, selling millions of records, no one has written anything about it in any academic journal - arguably because it sounds too much like beer garden music, which is not what most academics want to hear if they are studying Latin American culture.

Polka rhythms were also a mainstay of English language bands in Texas, as were accordions. They were sufficiently popular that two thirds of the songs that reached the top ten of the country and western charts in the 1940s used accordion. Once again, nothing has been written about accordions or polka in country music, and it seems to me worth exploring - perhaps accordion polka provided a bridge between cowboy and hillbilly styles and the tastes of Central European immigrants in cities like Chicago and northern rural areas like the German farming community that produced the United States' most popular purveyor of polka, Lawrence Welk. (Someone exploring this terra incognita might start with Welk's two top-10 country chart hits.) Bill Monroe's bluegrass band had an accordion in its early years, and Spade Cooley's Western swing orchestra had two. Cooley's version of the most famous of all Western Swing instrumentals, »Steel Guitar Rag (Cooley 1994), though it was based on a blues guitar piece, has an accordion polka backing section that could have come right out of Central Europe. Even Bill Haley and the Comets, the first internationally popular rock ' $n$ ' roll band, started as a hillbilly group and had and accordion player.

Some readers may think I am stretching this point, but in 1940 the Los Angeles Times published the first big story on the hillbilly music boom on the West Coast (Ryan 1940), and the record it described as the biggest hillbilly hit in the United States was the Glahe Musette Orchestra's »Beer Barrel Polka, « which, like Cooley's record, featured an electric steel guitar along with an accordion. Will Glahe's record was recorded in Berlin in the late 1930s, and whether or not one classifies it as hillbilly music, it was one of 
the biggest hits in the United States in 1939 (J asen 2002: 19). I have not been able to find a single comment on the oddity of a German record topping the U.S. charts in that particular year - a perhaps unsurprising silence of history, but one that might bear further investigation.

This list of German-American connections may seem overdone or irrelevant to some readers, but I present it not only because of my German audience but because it fits well with my broader theme. I ran across much of this information while researching American pop music, but might not have paid attention to it if I had not already been immersed in Mexican music — »El Barrilito, « as they call Glahe's piece, remains common with border accordion conj untos. Once I started studying accordion polka in that context, I found that it kept turning up in other contexts, and realized I had been hearing it for years in those contexts without ever thinking about it. Such connections are interesting to me, and following those paths made me hear new things in music I thought I already knew well. For example, my Mexican research pointed me towards new ways of thinking about blues (Wald 2004, 2012), and the realization that I had misunderstood so much about blues, the music I knew best, led me to take a new look at mainstream pop music (Wald 2009). When I followed that trail, I found that much of what I had always believed about the evolution of popular music in the United States was profoundly misleading - not because I had failed to read pop music scholarship, but because I had been unaware of that scholarship's silences.

Popular music studies is a relatively new field, largely because the majority of pop fans are the sort of people who are traditionally disrespected and even disliked by academics. That has changed somewhat, but there is a continuing danger that we will take the term »popular music « as our banner, but maintain our old prejudices. My guitar teacher and philosophical mentor, Dave Van Ronk, used to note with amusement the way university folk music aficionados embraced J oni Mitchell: »Of course they like her, « he would say. "She's doing art song, Schubert lieder, and that music was invented for people like them. « One could make similar comments about popular music scholars who embrace the Velvet Underground or Sonic Youth, or whose studies of rap focus on virtuosic, socially conscious lyricists.

Of course there is nothing wrong with Schubert, or Mitchell, or the Velvet Underground, and nothing wrong with following one's personal taste. Indeed, one could argue that the most noble act we can do as popular music scholars is to focus attention on artists who are not widely popular - I find Katy Perry interesting, but she is doing just fine without my approval. So 
I am not attacking or criticizing scholars whose interests differ from mine. I am just trying to suggest that there are some very big worlds of popular music out there, and some interesting questions to be asked about why they are so big and popular, and why so many people love them and live in them. And to remind myself, as well as my readers, that we need to be aware not only of the music we embrace, preserve, and celebrate, but also of our silences.

\section{Bibliography}

Allen, Walter C. (1974). Hendersonia: The Music of Fletcher Henderson and His Musicians. Highland Park, NJ : Walter C. Allen.

Biggers, Earl Derr (1911). »The German Band. «In: Wallace and Frances Rice, The Humbler Poets: A Collection of Newspaper and Periodical Verse 1885-1910. Chicago: A.C. McClurg, pp. 303-304.

Borges, J orge Luis (2000) »El escritor argentino y la tradición. « In: Contratiempo, at http:// www. revistacontratiempo.com. ar/ borges_tradicion. htm (accessed 2nd September 2013).

Collier, James Lincoln (1983). Louis Armstrong: An American Genius. New York: Oxford University.

Gushee, Lawrence (2005). Pioneers of J azz: The Story of the Creole Band. New York: Oxford University.

Harris, Roxy (2006). New Ethnicities and Language Use. New York: Palgrave Macmillan.

Heath, Charles V. (2007) The Inevitable Bandstand: The State Band of Oaxaca and the Politics of Sound. Ph.D. diss. Tulane University.

Jasen, David A. (2002). A Century of American Popular Music: 1899-1999. New York: Taylor \& Francis.

J ones, Max / Chilton, J ohn (1988). Louis: The Louis Armstrong Story 1900-1971. New York: Da Capo.

Lomax, Alan (1993). The Land Where the Blues Began. New York: Dell.

Obrecht, Jas (Ed.) (1993). Blues Guitar: The Men Who Made the Music. San Francisco: Miller Freeman.

Rijven, Stan (1989). »Introduction. «In: Popular Music 8:3, pp. 215-219.

Rust, Brian (1969). J azz Records 1897-1942. Chigwell, Essex: Storyville Publications. Ryan, Don (1940). »Hillbilly Music. «In: Los Angeles Times, 3 March, H9.

Simonette, Helena (2001). Banda: Mexican Musical Life across Borders. Middletown, CT: Wesleyan University.

Starr, S. Frederick (1983). »The Rock Inundation. «In: The Wilson Quarterly 7:4, pp. 58-67.

Trouillot, Michel-Rolph (1995). Silencing the Past: Power and the Production of History. Boston: Beacon.

Wald, Elijah (2004) Escaping the Delta: Robert Johnson and the Invention of the Blues. New York: Amistad/ HarperCollins.

Wald, Elijah (2007). „Louis Armstrong loves Guy Lombardo! Acknowledging the smoother roots of jazz. «In: J azz Research J ournal 1:1, pp. 129-145. 
Wald, Elijah (2009) How the Beatles Destroyed Rock ' $n$ ' Roll: An Alternative History of Popular Music. New York: Oxford University.

Wald, Elijah (2012) Vom Mississippi zum Mainstream: Robert J ohnson und die Erfindung des Blues. Berlin: Rogner \& Bernhard.

Whitburn, J oel (1986). Pop Memories 1890-1954. Menomonee Falls, WI: Record Research Inc.

\title{
Discography
}

Armstrong, Howard (1998). Louie Bluie. Arhoolie Records CD 470.

Beatles, The (1995). Anthology. Apple CD 7243.

Cooley, Spade (1994). Spadella: The Essential Spade Cooley. Columbia/Legacy CK 57392.

Grupo Montez de Durango (2002). El Sube y Baja. Disa CD 724042.

\section{Filmography}

Louie Bluie (1986). Produced by Terry Zwigoff. Beverly Hills, CA: Pacific Arts Video.

\begin{abstract}
History consists not only of what is included but of what is left out. It is a mistake to study recordings as representations of what was played in the periods and places where they were made, because they were never intended for that purpose. Musicologists must be aware of who is listening to music, and why, and where, and also of our own tastes and prejudices. Boney $M$ and Katy Perry are examples of artists who have been massively popular and influential, but have been almost completely ignored by scholars of popular music. What does that say about scholars of popular music? How do we misunderstand or mischaracterize what we study? What might we learn if we approached our subject differently? For example, what if we thought less about the intellectual reception of sound through listening and more about the physical reception of sound through dancing? What if we thought of popular music less as an art form and more as entertainment for teenage girls, its primary consumers? How has German music been left out of the broader histories of international pop?
\end{abstract}

